\title{
Editorial
}

\section{The Ecology and Society NetWork}

\author{
Lance Gunderson $^{1}$ and Carl Folke ${ }^{2,3}$
}

Key Words: ecology and society; network; transdisciplinary science

\section{INTRODUCTION}

At the end the first decade of the 21st Century, we are in a transition phase in the evolution of the planet. Two relevant snapshots come to mind: the increasing levels of carbon-dioxide concentration in the atmosphere over the last 50 years and the sharp increase in global temperatures over the past 80 years. Both reveal human-induced global changes. The former shows how we have changed the earth's biogeochemical cycles by pumping carbon from underground stores and releasing it (through land clearing and combustion) into the atmosphere. The latter indicates that these biogeochemical changes lead to unintended consequences, such as fluctuating temperatures, altered rainfall patterns, and melting glaciers and sea ice among others. In fact, the recent great acceleration of human activities now suggests that we are challenging critical dynamic boundaries of the current Holocene state of our planet, the state in which human civilizations have flourished (see Rockström et al. 2009). World leaders are wrestling with climate and other global environmental challenges, searching for better policies (see Rosenberg 2009), and rethinking social contracts (see O'Brien et al. 2009). Globalization has come to dominate the economic, social, and political dimensions of our lives as well. Most of us live in urban areas, with institutions and markets that shape the surface of every corner of earth, and we are interconnected through the Internet and media, which allow for rapid spreading of information worldwide.

The word "network" was originally derived from a description of an interlaced structure that performed work, such as a network of canals. It was then used to describe the corporations that created radio and television. Some four decades ago, scientists and engineers created a new kind of network, one that allowed computers to exchange information. That was the birth of what we now know as the Internet.

A network is an appropriate metaphor for the enterprise of Ecology and Society. The journal is not a collection of paper volumes that reside in a small number of locales around the world. This virtual journal resides on computers linked throughout the world. It started as an experiment, as one of the first internet-based and open-access journals. The information that is produced, shared, and stored among those computers is the work of our network. And the network is highly dynamic, generating innovative approaches and new insights and propositions across scientific fields and with practice and policy. The current issue is certainly the embodiment of such inter- and transdisciplinary science.

\section{THE CURRENT ISSUE}

This issue of Ecology and Society presents 43 such contributions and four responses to earlier articles. It is an amazing set of contributions. In addition to the three mentioned above- -New directions for marine management through changes in ocean policy" (Andrew Rosenberg), the need to "Rethink social contracts in light of climatic change" (Karen O'Brien, Bronwyn Hayward, Fikret Berkes) and the "Planetary Boundaries approach" to socialecological development (Johan Rockström, Will Steffen and colleagues; the longer version of a feature published in Nature in September 2009) there are clusters of papers that deal with: 


\section{Critical Transitions and Social-Ecological Dynamics}

Marina Fischer-Kowalski and Jan Rotmans present an important paper on "Conceptualizing, observing, and influencing social-ecological transitions." There is a fascinating paper by Colin Beier, Amy Lauren Lovecraft, and Terry Chapin on the "Growth and collapse of a resource system in public lands governance and forest management in Alaska." In a similar vein, Jianchu $\mathrm{Xu}$, Louis Lebel, and Janet Sturgeon investigate "Functional links between biodiversity, livelihoods, and culture in a Hani swidden landscape in southwest China."

\section{Cross-Scale Institutional Interplay and the Problem of Fit}

Carina Keskitalo, Camilla Sandström, Maria Tysiachniouk, and Johanna Johansson analyze "Local consequences of applying international norms in relation to forest certification in northern Sweden, northern Finland, and northwest Russia." This article is the first in the newly opened Ecology and Society Special Feature "Understanding adaptive capacity in forest governance." Julia Ekstrom and Oran Young take on the challenge of "Evaluating functional fit between a set of institutions and an ecosystem" and Eeva Primmer and Steven Wolf present a paper on the "Empirical accounting of adaptation to environmental change: organizational competencies and biodiversity in Finnish forest management." Ryan Plummer provides new insights on "The adaptive comanagement process: an initial synthesis of representative models and influential variables" and Hugues Lorent, Ruth Sonnenschein, Georgios M. Tsiourlis, Patrick Hostert, and Eric Lambin address "Livestock subsidies and rangeland degradation in central Crete."

\section{Ecosystem Services and Their Values}

This topic is gaining a lot of focus through, e.g., the TEEB (The Economics of Ecosystems and Biodiversity) initiative. Matthew Sommerville, Julia Jones, and E. J. Milner-Gulland present "A revised conceptual framework for payments for environmental services" and Kathryn Lannas and Jane Turpie provide an empirical analysis on "Valuing the provisioning services of wetlands: contrasting a rural wetland in Lesotho with a periurban wetland in South Africa."

\section{Integration of Diverse Knowledge and Perception Systems}

In this highly dynamic area of research, Catherine Gagnon and Dominique Berteaux deal with the challenge of "Integrating traditional ecological knowledge and ecological science: a question of scale." Carla Gonzalez, Adelaide Clemente, Kurt Aagaard Nielsen, Cristina Branquinho, and Rui Ferreira dos Santos continue on the same theme with a paper on the "Human-nature relationship in Mediterranean streams: integrating different types of knowledge to improve water management" and Elizabeth Dinsdale extends the integration by "Linking ecological and perceptual assessments for environmental management: a coral reef case study." The central role of knowledge integration is stressed by Anna Lejon, Birgitta Malm Renöfält, and Christer Nilsson in their paper on "Conflicts associated with dam removal in Sweden." This set of papers ends with a contribution by Marianne Krasny, Keith Tidball, and Nadarajah Sriskandarajah on "Education and resilience: social and situated learning among university and secondary students."

\section{Assessing Human Use and Resource Appropriation}

Martina Weiß, Rüdiger Schaldach, Joseph Alcamo, and Martina Flörke discuss "Quantifying the human appropriation of fresh water by African agriculture" and Adrian C. Newton, Luis Cayuela, and colleagues contribute the article "Toward integrated analysis of human impacts on forest biodiversity: lessons from Latin America." The significance of the urban context is reflected in the paper by Michael Strohbach, Dagmar Haase, and Nadja Kabisch analyzing "Birds and the city: urban biodiversity, land use, and socioeconomics." Jacqueline Vadjunec and Dianne Rocheleau nicely illustrate counterintuitive results in "Beyond forest cover: land use and biodiversity in rubber trail forests of the Chico Mendes extractive reserve." The role of property rights in resource use is central in the contribution by Xuefei Yang, Andreas Wilkes, and colleagues on "Common and privatized: conditions for wise management of matsutake mushrooms in northwest Yunnan Province, China" as well as in 
Bruce Johnsen's assessment of historical salmon stock management in "Salmon, science, and reciprocity on the Northwest Coast". This set ends with a plea by Todd Lookingbill, Sujay Kaushal, and colleagues for policy to seriously consider that "Altered ecological flows blur boundaries in urbanizing watersheds."

Among the contributed papers there is also an interesting article on "Philosophical issues in ecology: recent trends and future directions" by Mark Colyvan, Stefan Linquist, William Grey, Paul Griffiths, Jay Odenbaugh, and Hugh Possingham.

\section{Special Features}

Ecology and Society has 11 ongoing special features in this issue. It seems as though half the articles published belong to a special feature. We encourage them, because their integrative, interdisciplinary nature is congruent with our vision of the journal. The special feature Do we need new management paradigms to achieve sustainability in tropical forests? (Guest Editor: Robert Nasi), will close this issue. It has been with us over several issues and we sincerely thank Robert Nasi for his devoted work on the feature.

The two following new special features are now open and have one or more articles published as part of the current issue:

Understanding adaptive capacity in forest governance (Guest Editor: Carina Keskitalo).

Compensation and reward for environmental services in the tropics (Guest Editors: Brent Swallow, Hein Mallee, Susan Poats, and K. V. Raju).

We very much encourage you to delve into these issues and discover the exciting contributions.

Finally, The Science and Practice of Ecology and Society Award has been given to the inspiring article "Social infrastructure to integrate science and practice: the experience of the Long Tom Watershed Council" by Rebecca L. Flitcroft, Dana C. Dedrick, Courtland L. Smith, Cynthia A. Thieman, and John P. Bolte. This award recognizes practitioners who translate the scientific findings and insights of the scholarly community to practical applications.

\section{SUMMARY}

As we close the 14th issue of the journal (and begin a new decade), we wish to thank all of the staff, editors, authors, and readers who comprise the network of scholars from diverse disciplines and backgrounds known as Ecology and Society. Without your contributions, the network and its important work would not exist. Now, more than ever, the work that emerges from the journal is needed as we collectively attempt to navigate our planetary transition.

Responses to this article can be read online at: http://www.ecologyandsociety.org/voll4/iss $2 /$ art44/ responses/

\section{LITERATURE CITED}

Beier, C., A. L. Lovecraft, and T. Chapin. 2009. Growth and collapse of a resource system: an adaptive cycle of change in public lands governance and forest management in Alaska. Ecology and Society 14(2): 5. [online] URL: http://www.ecology andsociety.org/vol14/iss2/art5/.

Binkley, D., and S. L. Duncan. 2009. The past and future of Colorado's forests: connecting people and ecology. Ecology and Society 14(2): 9. [online] URL: http://www.ecologyandsociety.org/vol14/iss2/ $\underline{\operatorname{art} 9 / .}$

Bouchard, J., A. T. Ford, F. E. Eigenbrod, and L. Fahrig. 2009. Behavioral responses of northern leopard frogs (Rana pipiens) to roads and traffic: implications for population persistence. Ecology and Society 14(2): 23. [online] URL: http://www.e cologyandsociety.org/vol14/iss2/art23/.

Colyvan, M., S. Linquist, W. Grey, P. Griffiths, J. Odenbaugh, and H. P. Possingham. 2009. Philosophical issues in ecology: recent trends and future directions. Ecology and Society 14(2): 22. [online] URL: http://www.ecologyandsociety.org/vol14/ iss $2 / \operatorname{art} 22 /$.

Dahlberg, A. C., and C. Burlando. 2009. Addressing trade-offs: experiences from conservation and development initiatives in the Mkuze wetlands, South Africa. Ecology and Society 14(2): 37. [online] URL: http://www.ecologyandsociety.org/vol14/ iss $2 / \operatorname{art} 37 /$. 
Dinsdale, E. A. 2009. Linking ecological and perceptual assessments for environmental management: a coral reef case study. Ecology and Society 14(2): 28. [online] URL: http://www.ecologyandsociety.org/ vol14/iss2/art28/.

Ekstrom, J. A., and O. R. Young. 2009. Evaluating functional fit between a set of institutions and an ecosystem. Ecology and Society 14(2): 16. [online] URL: http://www.ecologyandsociety.org/vol14/iss2/ art16/.

Huijser, M. P., J. W. Duffield, A. P. Clevenger, R. J. Ament, and P. T. McGowen. 2009. Cost-benefit analyses of mitigation measures aimed at reducing collisions with large ungulates in the United States and Canada; a decision support tool. Ecology and Society 14(2): 15. [online] URL: http://www.ecolog yandsociety.org/vol14/iss2/art15/.

Fischer-Kowalski, M., and J. Rotmans. 2009. Conceptualizing, observing, and influencing social-ecological transitions. Ecology and Society 14(2): 3. [online] URL: http://www.ecologyandsoc iety.org/vol14/iss2/art3/.

Flitcroft, R. L., D. C. Dedrick, C. L. Smith, C. A. Thieman, and J. P. Bolte. 2009. Social infrastructure to integrate science and practice: the experience of the Long Tom Watershed Council. Ecology and Society 14(2): 36. [online] URL: http: //www.ecologyandsociety.org/vol14/iss2/art36/.

Gagnon, C.A., and D. Berteaux. 2009. Integrating traditional ecological knowledge and ecological science: a question of scale. Ecology and Society 14 (2): 19. [online] URL: http://www.ecologyandsociety. org/vol14/iss2/art19/.

Goldstein, B. 2009. Resilience to surprises through communicative planning. Ecology and Society 14 (2): 33. [online] URL: http://www.ecologyandsociety. org/vol14/iss2/art33/.

Gonzalez, C., A. Clemente, K. A. Nielsen, C. Branquinho, and R. Ferreira dos Santos. 2009. Human-nature relationship in Mediterranean streams: integrating different types of knowledge to improve water management. Ecology and Society 14(2): 35. [online] URL: http://www.ecologyandso ciety.org/vol14/iss2/art35/.

Grosman, P. D., J. A. G. Jaeger, P. M. Biron, C. Dussault, and J.-P. Ouellet. 2009. Reducing moose-vehicle collisions through salt pool removal and displacement: an agent-based modeling approach. Ecology and Society 14(2): 17. [online] URL: http://www.ecologyandsociety.org/vol14/iss2/ $\underline{\operatorname{art17/}}$.

Johnsen, D. B. 2009. Salmon, science, and reciprocity on the Northwest Coast. Ecology and Society 14(2): 43. [online] URL: http://www.ecolog yandsociety.org/vol14/iss2/art43.

Keskitalo, E. C. H., C. Sandström, M. Tysiachniouk, and J. Johansson. 2009. Local consequences of applying international norms: differences in the application of forest certification in northern Sweden, northern Finland, and northwest Russia. Ecology and Society 14(2): 1. [online] URL: http://www.ecologyandsociety.org/vol14/ iss2/art1/.

Kilbane Gockel, C., and L. C. Gray. 2009. Integrating conservation and development in the Peruvian Amazon. Ecology and Society 14(2): 11. [online] URL: http://www.ecologyandsociety.org/vol14/ iss2/art11/.

Krasny, M. E., K. G. Tidball, and N. Sriskandarajah. 2009. Education and resilience: social and situated learning among university and secondary students. Ecology and Society 14(2): 38. [online] URL: http://www.ecologyandsociety.org/voll4/ iss $2 / \operatorname{art} 38 /$.

Lannas, K. S. M., and J. K. Turpie. 2009. Valuing the provisioning services of wetlands: contrasting a rural wetland in Lesotho with a peri-urban wetland in South Africa. Ecology and Society 14(2): 18. [online] URL: http://www.ecologyandsociety.org/vol14/ iss $2 / \operatorname{art} 18 /$.

Lejon, A. G. C., B. Malm Renöfält, and C. Nilsson. 2009. Conflicts associated with dam removal in Sweden. Ecology and Society 14(2): 4. [online] URL: http://www.ecologyandsociety.org/vol14/ iss $2 / \operatorname{art} 4 /$.

Lookingbill, T. R., S. S. Kaushal, A. J. Elmore, R. Gardner, K. N. Eshleman, R. H. Hilderbrand, R. P. Morgan, W. R. Boynton, M. A. Palmer, and W. C. Dennison. 2009. Altered ecological flows blur boundaries in urbanizing watersheds. Ecology and Society 14(2): 10. [online] URL: http://www.e cologyandsociety.org/vol14/iss2/art10/.

Lorent, H., R. Sonnenschein, G. M. Tsiourlis, P. 
Hostert, and E. Lambin. 2009. Livestock subsidies and rangeland degradation in central Crete. Ecology and Society 14(2): 41. [online] URL: http://www.ecologyandsociety.org/vol14/iss2/art41/

Nasi, R., and P. G. H. Frost. 2009. Sustainable forest management in the tropics: is everything in order but the patient still dying? Ecology and Society 14(2): 40. [online] URL: http://www.ecologyandso ciety.org/vol14/iss2/art40/.

Newton, A. C., L. Cayuela, C. Echeverría, J. J. Armesto, R. F. Del Castillo, D. Golicher, D. Geneletti, M. Gonzalez-Espinosa, A. Huth, F. López-Barrera, L. Malizia, R. Manson, A. Premoli, N. Ramírez-Marcial, J. Rey Benayas, N. Rüger, C. Smith-Ramírez, and G. WilliamsLinera. 2009. Toward integrated analysis of human impacts on forest biodiversity: lessons from Latin America. Ecology and Society 14(2): 2. [online] URL: http://www.ecologyandsociety.org/vol14/iss2/ art2/.

O'Brien, K., B. Hayward, and F. Berkes. 2009. Rethinking social contracts: building resilience in a changing climate. Ecology and Society 14(2): 12. [online] URL: http://www.ecologyandsociety.org/vol14/ iss2/art12/.

Plummer, R. 2009. The adaptive co-management process: an initial synthesis of representative models and influential variables. Ecology and Society 14(2): 24. [online] URL: http://www.ecolog yandsociety.org/vol14/iss2/art24/.

Primmer, E., and S. A. Wolf. 2009. Empirical accounting of adaptation to environmental change: organizational competencies and biodiversity conservation in Finnish forest management. Ecology and Society 14(2): 27. [online] URL: http: //www.ecologyandsociety.org/vol14/iss2/art27/.

Reeves, G. H., and S. L. Duncan. 2009. Ecological history vs. social expectations: managing aquatic ecosystems. Ecology and Society 14(2): 8. [online] URL: http://www.ecologyandsociety.org/vol14/iss2/ art8/.

Rockström, J., W. Steffen, K. Noone, А̊. Persson, F. S. Chapin, III, E. Lambin, T. M. Lenton, M. Scheffer, C. Folke, H. Schellnhuber, B. Nykvist, C. A. De Wit, T. Hughes, S. van der Leeuw, H. Rodhe, S. Sörlin, P. K. Snyder, R. Costanza, U. Svedin, M. Falkenmark, L. Karlberg, R. W.
Corell, V. J. Fabry, J. Hansen, B. Walker, D. Liverman, K. Richardson, P. Crutzen, and J. Foley. 2009. Planetary boundaries: exploring the safe operating space for humanity. Ecology and Society 14(2): 32. [online] URL: http://www.ecolog yandsociety.org/vol14/iss2/art32/.

Rosenberg, A. A. 2009. Changing U.S. ocean policy can set a new direction for marine resource management. Ecology and Society 14(2): 6. [online] URL: http://www.ecologyandsociety.org/vol14/iss2/ $\underline{\operatorname{art} 6 / .}$.

Sommerville, M. M., J. P. G. Jones, and E. J. Milner-Gulland. 2009. A revised conceptual framework for payments for environmental services. Ecology and Society 14(2): 34. [online] URL: http://www.ecologyandsociety.org/vol14/iss2/ $\underline{\operatorname{art} 34 / .}$.

Stirling, A. C., and I. Scoones. 2009. From risk assessment to knowledge mapping: science, precaution, and participation in disease ecology. Ecology and Society 14(2): 14. [online] URL: http: //www.ecologyandsociety.org/vol14/iss2/art14/.

Strohbach, M. W., D. Haase, and N. Kabisch. 2009. Birds and the city: urban biodiversity, land use, and socioeconomics. Ecology and Society $\mathbf{1 4}$ (2): 31. [online] URL: http://www.ecologyandsociety. org/vol14/iss2/art31/.

Swallow, B. M., M. F. Kallesoe, U. A. Iftikhar, M. van Noordwijk, C. Bracer, S. J. Scherr, K. V. Raju, S. V. Poats, A. Kumar Duraiappah, B. O. Ochieng, H. Mallee, and R. Rumley. 2009. Compensation and rewards for environmental services in the developing world: framing pantropical analysis and comparison. Ecology and Society 14(2): 26. [online] URL: http://www.ecolog yandsociety.org/vol14/iss2/art26/.

Taylor, B. D., and R. L. Goldingay. 2009. Can road-crossing structures improve population viability of an urban gliding mammal? Ecology and Society 14(2): 13. [online] URL: http://www.ecolog yandsociety.org/vol14/iss2/art13/.

Thomas, D., M. Weedermann, L. Billings, J. Hoffacker, and R. A. Washington-Allen. 2009. When to spray: a time-scale calculus approach to controlling the impact of West Nile virus. Ecology and Society 14(2): 21. [online] URL: http://www.e cologyandsociety.org/vol14/iss2/art21/. 
Vadjunec, J. M., and D. Rocheleau. 2009. Beyond forest cover: land use and biodiversity in rubber trail forests of the Chico Mendes Extractive Reserve. Ecology and Society 14(2): 29. [online] URL: http: //www.ecologyandsociety.org/vol14/iss2/art29/.

van der Ree, R., D. Heinze, M. McCarthy, and I. Mansergh. 2009. Wildlife tunnel enhances population viability. Ecology and Society 14(2): 7. [online] URL: http://www.ecologyandsociety.org/vol14/ iss2/art7/.

van Langevelde, F., and C. F. Jaarsma. 2009. Modeling the effect of traffic calming on local animal population persistence. Ecology and Society 14(2): 39. [online] URL: http://www.ecologyandso ciety.org/vol14/iss2/art39/

Wardwell, D., and C. R. Allen. 2009. Variability in population abundance is associated with thresholds between scaling regimes. Ecology and Society 14(2): 42. [online] URL: http://www.ecolog yandsociety.org/vol14/iss2/art42/.

Weiß, M., R. Schaldach, J. Alcamo, and M. Flörke. 2009. Quantifying the human appropriation of fresh water by African agriculture. Ecology and Society 14(2): 25. [online] URL: http://www.ecolog yandsociety.org/vol14/iss2/art25/.

Xu, J., L. Lebel, and J. Sturgeon. 2009. Functional links between biodiversity, livelihoods, and culture in a Hani swidden landscape in southwest China. Ecology and Society 14(2): 20. [online] URL: http: //www.ecologyandsociety.org/vol14/iss2/art20/.

Yang, X., A. Wilkes, Y. Yang, J. Xu, C. S. Geslani, X. Yang, F. Gao, J. Yang, and B. Robinson. 2009. Common and privatized: conditions for wise management of matsutake mushrooms in Northwest Yunnan province, China. Ecology and Society 14 (2): 30. [online] URL: http://www.ecologyandsociety. org/vol14/iss2/art30/. 